\title{
GEOINFORMATION TOOLS PROVIDING ESTIMATIONS OF VEGETATION AREAL DAMAGES CAUSED BY WILD FIRE DISASTERS
}

\author{
Victor Savorskiy ${ }^{1,2,}$, , Sergey Bartalev ${ }^{2}$, Aleksandr Kashnitskiy ${ }^{2}$, Aleksey Mazurov², Olga Panova ${ }^{1,2}$, Fedor Stytsenko ${ }^{2}$ \\ ${ }^{1}$ Space Research Institute RAS, 117997, 84/32 Profsoyuznaya Str, Moscow, Russia - evgeny@d902.iki.rssi.ru \\ ${ }^{2}$ Kotel'nikov Institute of Radioengineering and Electronics of Russian Academy of Sciences, Fryazino Department, \\ Vvedenskogo sq., 1, Fryazino, Moscow region, Russia - savor@inbox.ru
}

Commission VI, WG VI/4

KEY WORDS: Web Tool, Information System, Damage, Vegetation, Disaster, Event, Forest Fire

\begin{abstract}
:
The object of this work is to develop web tools, which provide remote services necessary for disaster management purposes in domain of satellite Earth observation (EO) of vegetation areal, primarily forest or agricultural areas damaged by wild fires. The main idea for application of developed web tools is to provide targeted users with estimation instrument that allows not only to predict future or to detect existed perturbations in vegetation canopy but to estimate damage extent caused by disasters as well. To estimate damage extent of future possible disaster the developed services use historical data on vegetation canopy parameter both with hydrometeorology data on current weather conditions. Specialized EO data routines produce a set of products, which are required to make reliable prediction of possible damage extent subject to current weather conditions. In addition, the tools for estimation consequences of actual disaster event in vegetation areal are developed. In this case, special service compares actual state of vegetation canopy, which is retrieved from actual EO information, with historical information, which is extracted from special database that contains information on vegetation canopy status immediately before disaster event. This comparison allows not only to estimate the extent of actual damage but also to forecast disaster effects on future consequences, i.e. to estimate finally expected damage extent. Developed tools incorporate both forecasting and nowcasting possibilities to estimate damage extents. All necessary supporting services are implemented in active satellite data information system (IS) incorporated with long-term EO data archive. This incorporation allows upgrading possibilities of information system in disaster management support, namely in fast and reliable estimation of current and eventual damages.
\end{abstract}

\section{INTRODUCTION}

Every year forest fires cause significant damage to the national economy of Russia. To combat this natural disaster and its consequences, large-scale regional and federal efforts are being made. The effective implementation of such efforts depends to a large extent on the timely receipt and rapid analytical assessment of current information Earth observation (EO) on the status and forecasts of the development of a fire hazardous situation in a controlled forest area.

First of all, to deal with this problem it is necessary to assess the seasonal degree of fire danger, i.e. a priori probability of a fire occurrence at least in any relative but comparative units. In addition, accounts for real synoptic situation substantially refine these damage forecasts. So, it is important not only use historical data but as well take into account recent (at day and decade time scale) and current synoptic situation to update probability estimations.

Second, it is necessary to be able to quickly evaluate the damage caused by current fires, i.e. fires, which are really observed from satellites. For these purposes, satellite data should be used primarily for forest fire detection and estimation of the spatial visible size of damaged forest spot. In addition, in order to estimate damage extent in natural expression one should use information on specific wood stock of damaged forest plots. To estimate damage in monetary form one need to use forest taxonomy of damaged forest plots as well. It allows comparing the fire damages for a number of Russian regions with significantly different geographical and climatic conditions.

Third, may be the most important thing is the necessity to evaluate predicted damages caused by running fires. Such forecast allows us to estimate a priori all potential damage from the fire in full development. Namely an ability to evaluate a priori the fire damage will make it possible to plan and promptly adjust existing plans for fire extinguishing measures, and, no less important, to minimize fire consequences and timely protect population.

Geoinformation tools, which support all above-mentioned evaluations, provide information similar by content to "event intensity" used in ranking procedures (Savorskiy and Tishchenko, 2008; Savorskiy and Tishchenko, 2009; Savorskiy and Tishchenko, 2012). These ranking procedures are initiated by event intensity above the preset threshold. Such approach allows to actualize the description of a zone of a natural disaster by the most appropriate data which describing this event, i.e. to reflect the most adequate actual state of the disaster zone.

This work goal is to develop web tools that are intended to be used for disaster management in case of forest fire. In this case we have to determine both actual fire damage and forecasted finally expected consequences. Namely for these purposes the most appropriate approach is to use damage extent estimations, which could be considered as one of possible extension of "event intensity" entity. Therefore, the work examines possibilities to 
use satellite data for estimations of direct damage caused by forest fires in Russia. This is an upgrade of referenced methodology (Savorskiy and Tishchenko, 2008). This upgrade should allow using EO data not only for visualization but also for evaluation of damage extent in monetary form.

In order to retrieve necessary forest taxonomy the presented work develops methodology based on approaches of satellite data processing and interpretation elaborated during last two decades in Institute of space researches of RAS (IKI RAS) (Egorov et al., 2006; Bartalev et al., 2015a; Bartalev et al., 2015b; Bartalev et al., 2016). In addition, the work engaged information resources of VEGA satellite service (Lupyan et al., 2014), enabling access to specified historical and statistical information resources necessary to calculate probability features of forest fire events. VEGA focuses on solving problems associated with the study and monitoring of vegetation cover including explorations of forest fires. That is why VEGA service was chosen by us as a platform for the development of a specialized service providing objective remote assessments of damage caused by forest fires.

The main content of the work is the upgrade of services and corresponding software (SW) web tools of the VEGA system, which allows to quickly estimate the direct damage of observed fire and the potential damage accounting future (after observation) fire developments calculated by IKI RAS methodology (Bartalev et al., 2017). Both estimations are presumed to be expressed in monetary form. In addition, VEGA web tools supporting estimations of fire threats in relevant, i.e. non- monetary, form. Nevertheless, it is applicable for planning purposes since it allows comparative analysis of threats.

\section{DAMAGE ESTIMATION REQUIREMENTS}

\subsection{Possibilities to increase objectivity of decisionsin in fire extinguishing procedures}

Traditionally, one of the most discussed problems associated with organizing the protection of forests from fires is to decide which fires should be extinguished, and which ones should only be controlled. A well-founded answer to this question could significantly reduce costs by sending funds and resources to the fires that are necessary to extinguish, and thereby to increase the effectiveness of actions, which should protect forests and infrastructure from forest fires. Note that the basis for deciding whether to extinguish a particular fire actually lies in two main factors. First is assessment of whether a particular fire represents a threat to infrastructure facilities and human settlements. Second is the results of a comparison of the means necessary to extinguish the fire with potential expected damage to forests and/or other natural objects, which this fire can cause. The decision to extinguish a particular fire can be based on obvious scheme, shown in Figure 1.

It should be noted that application of such a decision-making scheme is especially important in cases of spring and autumn fires, as a result of which damage in percentage of forest mortality is usually minimal (Bartalev et al., 2015b). In particular, such fires are the majority of fires that occur in the Primorsky Kray territory. One of the main difficulties in using such a scheme in practice is that there is usually no objective information for its implementation and, accordingly, decisionmaking. But VEGA services, e.g. in VEGA-Primorie realisation (Loupian et al., 2016), contain basic elements that could become the basis for the introduction of such a scheme. Namely, the systems that implement:

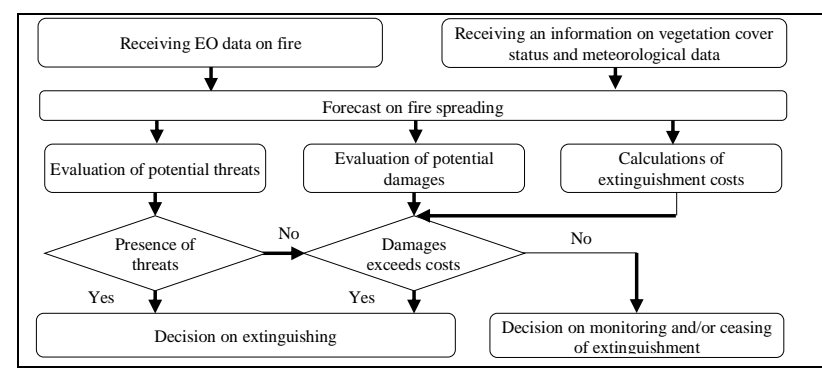

Figure 1. Possible scheme for deciding whether to extinguish a fire (Loupian et al., 2016)

- the possibility of obtaining objective information for modeling the processes of wildfire spreading;

- the possibility of modeling and assessment of potential threats and damages (in natural form);

- obtaining the estimates of the current fire parameters (including the characteristics of the propagation fronts), necessary for calculating the forces and means to conduct the extinguishment (in fact, estimating the potential costs).

Note that this information is actually obtained in an automated mode, so it does not depend on subjective opinions and therefore can be used in developing the objective recommendations for making decisions. To enable automated comparison of finally expected damages this work develops algorithm of evaluating direct damages from forest fires in monetary form, which is mandatory for comparison them with extinguishment costs.

\subsection{Algorithm of damage evaluation}

The direct damage from forest fire should be evaluated in monetary form because it allows forming basis for the most effective disaster management policy for vast regions with sufficiently different types of natural resources. For these purposes it is worthwhile to use the state rates of payment for a unit of forest resources (Government Decree, 2007) updated by inflation correction coefficients, currently referenced by (Government Decree, 2016).

To reduce the time required to obtain damage estimations from satellite monitoring data, it is necessary to automate this procedure. It requires developing the formal algorithm of the damage evaluations. That is why in this section the procedure for calculating damage fire disaster is presented in the form of formal relations, which together allow obtaining the required evaluations. These relations form a formal algorithm, easily implemented in the form of software utilities, including web tools.

The calculation of direct damage is made according to the following relationships:

$$
\begin{aligned}
& D=P \times \Delta W, \\
& P=T * D(t) * G,
\end{aligned}
$$

where $P$ is the value of the damage per one unit of wood stock in monetary form adjusted for the forest taxonomy and the year of disaster; $T$ is the basic damage per one unit of wood stock in monetary form; $D(t)$ is the correction factor to the fee rates for the unit of forest resources volume for the year, currently referenced by (Russian Federation Government Decree, 2016); $G$ is the coefficient of damage accounting for protecting forests $(G$ $=2$ ), for specially protected forests $(\mathrm{G}=3)$, and specially protected natural areas $(G=5)$. 
Basic damage per one unit of wood stock in monetary form is given by relations:

$$
T=\alpha(t) *\left(\sum_{\text {con }} k_{i} P_{i}\right)+\left(\sum_{\text {dec }} k_{k} P_{k}\right)
$$

Here $k_{i}, k_{k}$ are the coefficients of the composition of the stand (in the decimal proportions of the composition of the stand): 1) the index $i$ denotes samples of coniferous ("con") species; 2) the index $k$ denotes samples of deciduous ("dec") species; $P_{i}, P_{k}$ - rates of payment for a unit of wood volume of the $i$-th coniferous or $k$-th deciduous hardwood in the forest taxation region where a forest fire or its consequences («gar'» - burnt place in the forest) is detected; $\alpha(t)$ is the coefficient of seasonal damage value for coniferous species, depending on the season of disaster: $\alpha(t)=2$ in December-January and $\alpha(t)=1$ in February - November.

As it can be seen from the relationships (1-3) the direct damage of forest fire can be calculated according to the volume of damaged wood $\Delta W$, the correction factors $\alpha(t)$ and $D(t)$, depending on the date of disaster, and the taxonomic description of the forest area where disaster was detected. The volume of damaged wood is defined as

$$
\begin{aligned}
& \Delta W=W_{a}-W_{p}, \\
& W_{a}=w * S,
\end{aligned}
$$

where $S$ is square of damaged area, $W_{a}, W_{p}$ are the total wood stocks on the damaged site before and after disaster. It should be noted that when disaster damages the whole stock, i.e. at $W_{p}=$ 0 , expression (5) is substantially simplified

$$
\Delta \mathrm{W}(0)=\mathrm{W}_{\mathrm{a}}=\mathrm{w}^{*} \mathrm{~S}
$$

where $\mathrm{w}$ is specific wood stock per one unit of square. To estimate the wood stocks on the damaged site before disaster it is necessary to use taxonomy descriptions of this site. Usually such description is received from the materials of the state forest inventory. However, analysis conducted in (Savorskiy et al., 2017) revealed that the data from state forest inventory should be substantially corrected before using in damage estimations due to the problems of inventory actualization during inventory preparation and updating procedures. Therefore VEGA information resources, namely long-term data and products of EO observations of Russian forest terrains, which are contained in VEGA archives, were used for the taxonomy descriptions of forest stands before forest fire disaster event.

\subsection{Requirements for retrieved forest taxonomy}

As it follows from relations (1-6), in order to calculate the amount of damage from forest fire, it is necessary to have up-to-date objective information on forest taxonomy retrieved from EO including:

1) the coordinates of the boundaries of the forest site damaged by fire with spatial resolution not worse than 5-10 m, which is necessary for the current assessment of location and square of the damaged area,

2) specific or full wood stock of damaged areas, which is necessary to assess the extent of damage in natural units, i.e. in $\mathrm{m}^{3}$,

3) the types of tree vegetation, the tree species composition of the stand and the extent of its damage, which is necessary to estimate the amount of direct damage from the destruction of renewable resources in monetary form,
4) date of fire passage, which allow to establish the cause and effect factors that determine the origin and consequences of a fire,

5) in addition forecast of forest fire development requires information on current and previous (at least during one month) hydrometeorology information.

\subsection{Requirements for web tool functionality}

One more requirement arises from necessity to incorporate different information received from distributed data sources. Effective solution of this problem is possible only via using virtual integration approach in distributed information system environment. One of the basic feature of such approach is the usage of common web interface, which allows accessing all distributed, including remote, information resources from one access point. In our case such interface provides access to a set of software web tools necessary for estimating the damages caused by forest fire.

Selection web tools are of great importance for disaster management purposes due to the necessity to search and retrieve a variety of data sets often describing the vast regions of interest. Therefore, search and detection of targeted objects by standard means (Savorskiy et al., 2014), i.e. without any auxiliary information, is very difficult and time-consuming procedure leading to inefficient use of system services. For damage investigation purposes it is necessary to use combine search methodology described in (Savorskiy et al., 2016a).

Along with search and selection capabilities, the set of web tools should provide access to analytic software instruments both of general-purpose and of special kind, e.g. as that which are described in paper (Kashnitskiy et al., 2015). General-purpose web tools are designed for exploration of a variety of Earth objects in contrast to more specialized ones oriented for investigation of a definite type, or class, of natural objects. General-purpose functionalities should provide:

- web mapping (cartographic) interfaces for user access to satellite data resources;

- $\quad$ space data visualization procedures;

- data classification;

- $\quad$ spectral analyzers.

Special web tools should support

- functionality of spectral portraits system which retrieves and manages natural object signatures or descriptors;

- $\quad$ spectral index management system for investigation of vegetation canopy (including investigation of forest fire features and consequent damages).

\section{IMPLEMENTATION OF GEOINFORMATION WEB TOOLS}

Currently there is an abundance of EO IS (see e.g. references in (Loupian et al., 2012)) providing web access to catalogues and archives of EO data. However, implementations of SW web tools to work with $\mathrm{EO}$ data, i.e. to analyse and process them by user requests in remote mode via common Web interfaces of an EO IS, are scarce. Such type of IS was implemented in VEGAConstellation IS family by research and development team of the Space Research Institute of the Russian Academy of Sciences (IKI RAS) (Loupian et al., 2011; Bartalev et al., 2012; Uvarov et al., 2014; Savorskiy et al., 2014; Savorskiy et al., 2016a, VEGA, 2017). Design and development of VEGA-Constellation information systems is based on original GEOSMIS technology also elaborated by the IKI RAS team. 
3.1 Potential possibilities of VEGA satellite services for direct operational assessments of damage from natural disasters caused by forest fires

Taking into account the specifics of modern technologies for decoding satellite imagery it is necessary to recognize the approach proposed in (Loupian et al., 2012) as a highly effective, and perhaps the best way to organize procedures for monitoring forest fire damages. The basic idea of the approach is in physical storage of all information resources, which is necessary to solve targeted task, in a limited number of large well-equipped centers for EO data collection, storage, and processing and dissemination of retrieved products. It is also assumed that all these procedures are equipped with software and hardware to support the services that are necessary and/or in demand for remote work of targeted users, namely, to support the remote services that monitor forest fires and enable evaluation of produced damages. The set of these services should include not only SW means of searching, localizing and obtaining the initial EO data and the results of their primary, i.e. non-oriented to end-user requests, processing.

They also should include specialized web tools for analyzing EO data and products, as well as services that provide the results of processing (products) in a form suitable for direct use by the endusers, both in format and in content. Such products should allow them to estimate the extent of damage caused by forest fires. At the same time, specialized analytical web tools should ensure timely receipt of such evaluations based on updated, i.e. actualized, objective data of satellite monitoring of forest resources. The above-mentioned functionality is provided by VEGA satellite services and systems created on VEGA technological basis, which are oriented to solve the problems related to research and monitoring of vegetation cover (Bartalev, et al., 2012; Loupian et al., 2014). That is why VEGA service we is chosen as the platform for the development of a specialized services that provide objective, current, remote assessments of damage to forests caused by natural disasters such as forest fires.

VEGA family of services (VEGA, 2017) currently has a welldeveloped methodological and SW base (see, for example, (Egorov et al., 2006; Bartalev et al., 2015a; Bartalev et al., 2015b; Bartalev et al., 2016). It makes possible to restore the characteristics of the state of forest cover from EO data. At present, this methodological base ensures reliably operations of a set of information services, which provide us with prototypes functionality of specialized tools for assessing damage from forest fires. In particular, the analysis showed that VEGA services have functional prototypes that ensure full compliance with requirements 1-4 in sec.2.2.
VEGA services «Natural fires», which enable exploration of forest fires and evaluating their consequences, i.e. damages, are accessed via VEGA main interface applying button. «Natural fires» panel allows searching and choosing geographic region of interest, period, and type of fires or their damages to be presented on viewing panel. As well, it provide users with common web tools to scale images and to attributes them with descriptions. Figure 2 reveals such viewing panel with fire status information of the south part of Primorskiy Kray (Far-East Russia) in May 2017. Red polygons denote current forest fires while black ones denote damaged forest sites.

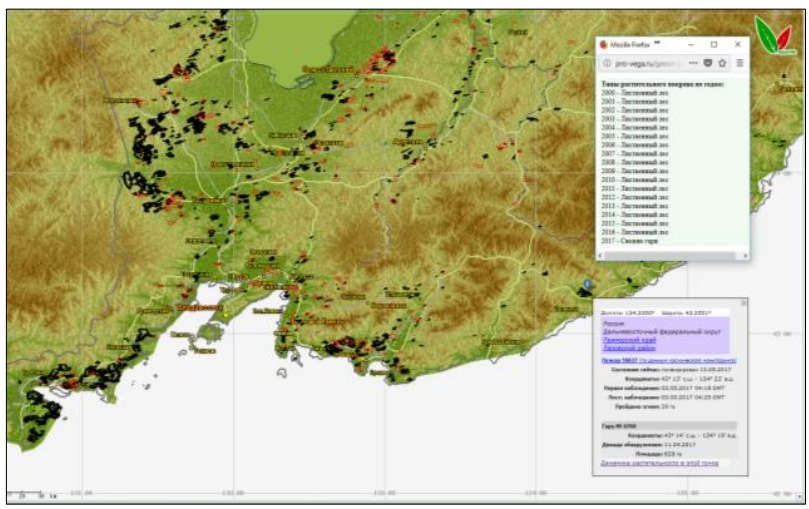

Figure 2. VEGA interface to monitor and analyze forest fires and damaged sites

Upper right subpanel presents list of vegetation types for quested test point . In particular presented list reveals that tested area has deciduous forest until Spring 2017 when it was damaged by fires. Currently it is damaged forest site ("garj"). Lower right subpanel presents attributes of damaged site. In particular it contains information on date of last fire (May 2017), on its location $\left(43^{\circ} 13^{\prime} \mathrm{N}, 134^{0} 22^{\prime} \mathrm{E}\right)$, and its size ( 39 ha). In addition this subpanel informs on the size of damaged forest ( $828 \mathrm{ha})$ and central points of its location $\left(43^{\circ} 14^{\prime} \mathrm{N}, 134^{0} 19^{\prime} \mathrm{E}\right)$. Location and the square size of damaged forest provide core information for further damage estimations.

Figure 3 reveals pipeline of procedures which uses complex of EO data for detection and monitoring of forest fires and their consequences, i.e. damages. Starting with fires detection procedure this pipeline finishes with installation of dead forest boundaries. Namely dead forest boundaries give us final information on square of damaged area and on total or specific wood stocks on the damaged after disaster (see relations (4-6)).

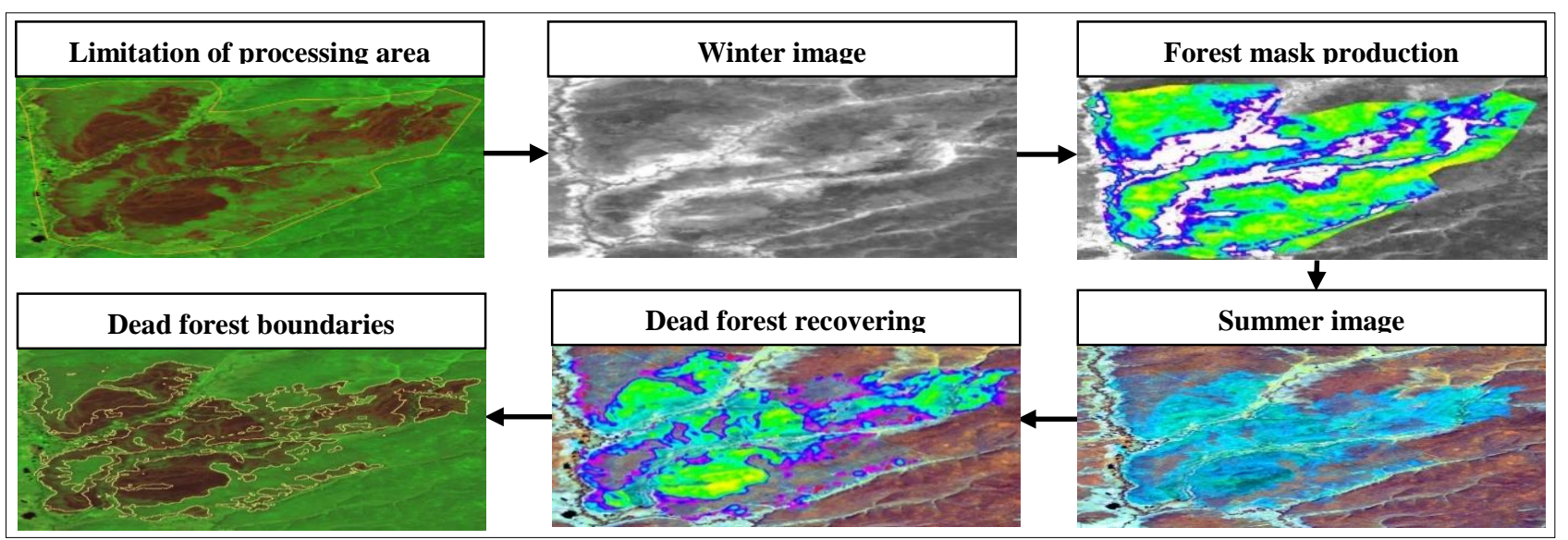

Figure 3. Technology of detection and mapping forest mortality by using EO data 
Necessity to use additional information (with respect to primary EO data) for damage estimation is revealed by fire image in Figure 4. It is obvious from it that final size of damage will exceed visible size that is observed in image. But it is also the problem with estimations of forest fracture which survives in fire. So, we must measure or estimate $W_{p}$ value. Namely, that is the main content of procedures described by scheme in Figure 3 which would provide us with information on dead forest boundaries, i.e. true spatial size of damage.

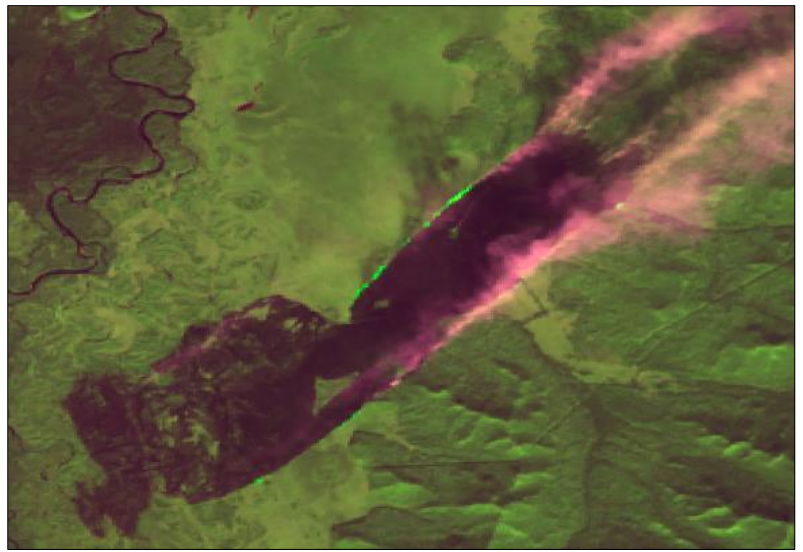

Figure 4. EO data used for fire detection. Lansat 8, 11.04.2015, Primorskiy Kray (Far-East Russia)

Another necessary forest parameter needed to estimate damage extent is wood stock of forest plot that is exposed by fire. This parameter could be directly used in expressions $(5,6)$ for evaluation of current and potential damage extents. In regular practice of forest management the wood stock values should be retrieved from Russian forest inventory data base. But due to problems with inventory actualization very often it is necessary to use others sources of information on wood stock values. VEGA services implement its own methodology on wood stock retrieval by using multiyear EO (Bartalev et al., 2017). Figure 5 reveals an example of VEGA application for wood stock estimations in Primorskiy Kray (Far-East Russia).

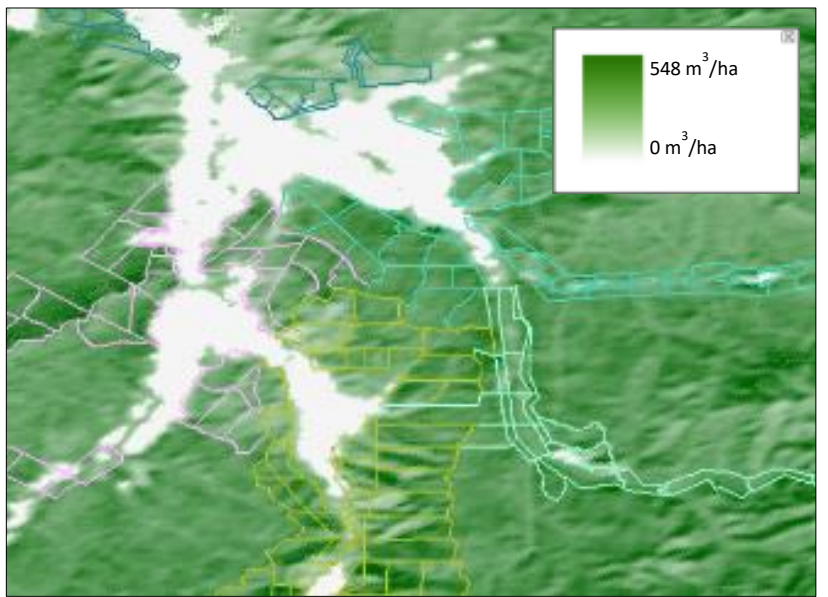

Figure 5. Specific wood stock distribution. Primorskiy Kray (Far-East Russia) (Savorskiy et al., 2016b)

${ }^{1}$ Stock rate is updated using correction coefficient $D(t)=1.37$ for year 2018 (Russian Federation Government Decree, 2016)

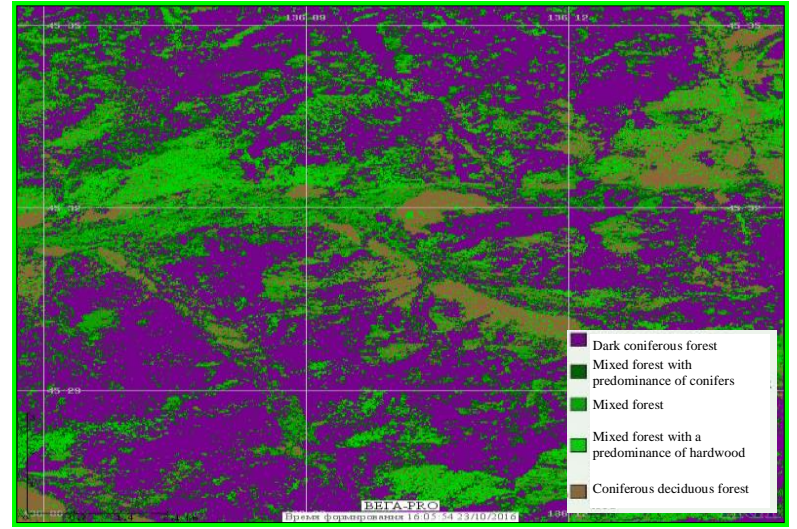

Figure 6. Distribution of prevailing tree species. Primorskiy Kray (Far-East Russia). (Loupian et al., 2016)

As follows from expression (5) in order to estimate damage, we should know tree species composition of forest territory undergone by fire. As mentioned above state forest inventory could be used to get knowledge on it. But unfortunately the inventory often contain non-actualized or unreliable data. In those cases it is worthwhile to use IKI methodology which retrieve actual tree species composition directly from EO data. The example of such information is presented in Figure 6 for the same site as in Figure 5.

Table 1 represents rates of typical wood stock, which can be used to evaluate fire damages in Primorskiy kray. Namely, it presents rates necessary to estimate damages of Siberian cider, oak, birch, and aspen forests. The table reveals real necessity to account for natural disaster damages in monetary form. In particular, it shows big difference between specific damage, i.e. forest damage equal 1 ha of wood, for cider and oak forests. They differ by more than three times for specific (per $1 \mathrm{ha}$ ) damages. Fire damage of forest site, presented in Figure 2, is evaluated by current state rates in $904946.04 \mathrm{rbl}$ for the case of full loss of oak forest.

\begin{tabular}{|c|c|c|c|}
\hline Tree species & $\begin{array}{c}\text { Specific stock, } \\
\mathrm{m}^{3} / \mathrm{ha}\end{array}$ & $\begin{array}{c}\text { Stock rate } \\
\mathrm{rbl} / \mathrm{m}^{3}\end{array}$ & $\begin{array}{c}\text { Specific damage, } \\
\mathrm{rbl} / \mathrm{ha}\end{array}$ \\
\hline Siberian cider & 208.7 & 222.63 & 46482.88 \\
\hline Oak & 151.1 & 1092.93 & 161141.72 \\
\hline Birch & 132.5 & 94.44 & 12513.30 \\
\hline Aspen & 126.5 & 18.50 & 2340.25 \\
\hline
\end{tabular}

Table 1. Typical wood stock rates in Primorskiy kray in 2018

3.2 The possibilities of VEGA services for assessing fire danger extent with increasing fire danger in the prevailing synoptic situation

VEGA services provide information for potential dangers in forest fire season. This information can be used for optimization of the distribution of firepower and means in preparation for fire season activity. This information is based on long-term statistics of fires and fire characteristics terrain under control. Such approach is worthwhile to use for control purposes of large terrains. Figure 7 shows the map with fire frequencies in south 
part of Primorskiy kray based on statistics acquired in period from 2001 to 2015 . Here you can see extremely high extent of fire danger to the north-east of Nakhodka which is prevailed place to be planned for forest fire extinguishment.

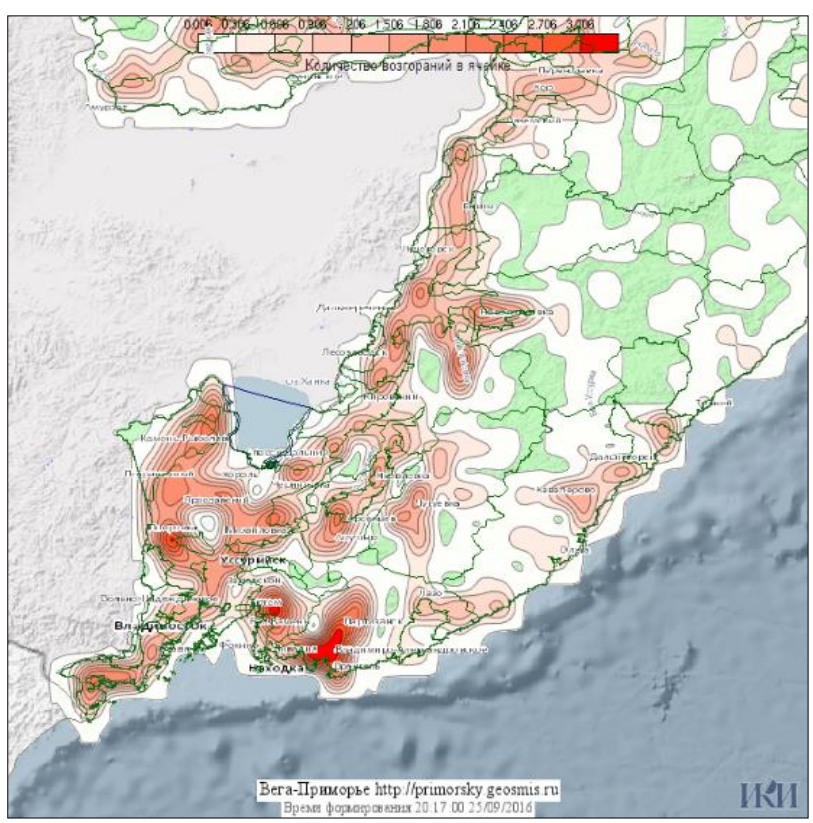

Figure 7. Distribution of the frequency of natural fire occurrence in the Primorsky krai (statistics for the period from 2001 to 2015) (Balashov et al., 2016)

Due to great volatility of temperature/humidity conditions both on year-to-year and inter-season scales, caused by synoptic instabilities, multiyear statistics should be substantially updated to be used in short term (up to a week) and midterm (up to 2-4 weeks) forest fire forecasts. VEGA services can provide such forecast using fire danger index (see description and motivation in (Khvostikov, 2016)). This index is based on spatial distributions of meteorological parameters determining the probabilities of forest fire ignitions. Typical map of such parameters is presented in Figure 8 for forest fire season in Zabaykalsiy kray (10.06.2017).
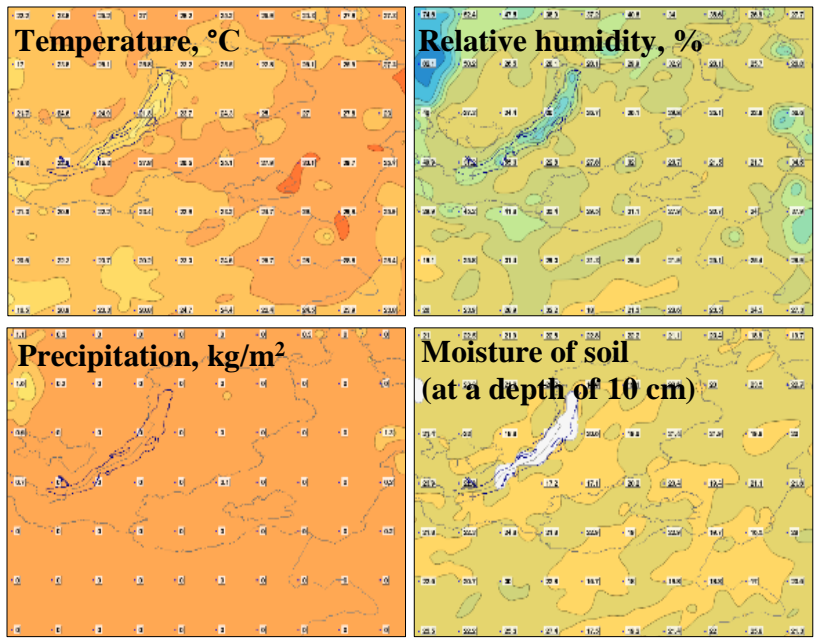

Figure 8. Maps of meteological parameters provided by VEGA services: temperature, are humidity, precipitation rate, soil moisture. Zabaykalsiy kray (10.06.2017)
3.3 The possibilities of VEGA services for assessing the finally expected damage in the development of the actually observed fire situation

To determine the finally expected fire damage and to decide whether to extinguish it, it is necessary to carry out operational prediction of pyrogenic forest death. Simulation modeling of fire development serves as a basis for operational forecasting, providing the possibility of constructing an advance forecast of the dynamics of fire propagation. The fire development model is implemented in the Rosleskhoz information system (Loupian et al., 2015), which exemplifies the possibility of predicting pyrogenic forest deaths using VEGA services. The model is described in detail in previously published papers (see (Khvostikov et al., 2012; Khvostikov et al., 2016; Bartalev et al., 2017)). Figure 8 presents the principal modeling scheme that describes spreading of forest fire.

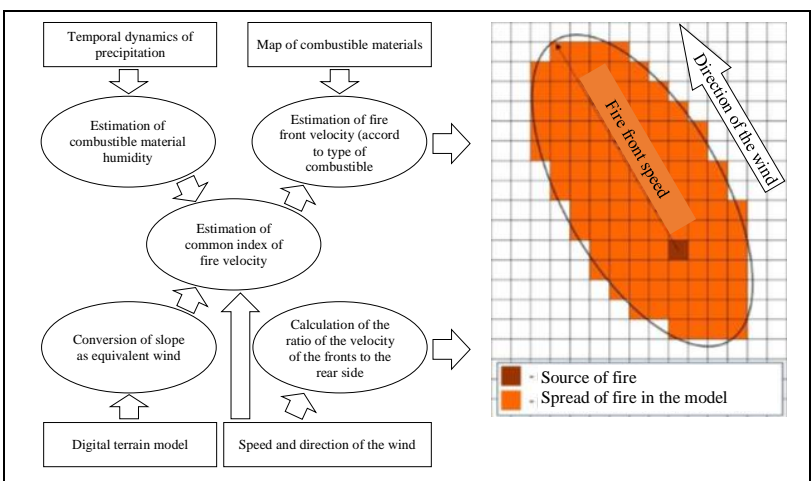

Figure 8. General modeling scheme of forest fire spreading (Khvostikov et al., 2012; Khvostikov et al., 2016; Bartalev et al., 2017)

To simulate the development of a fire, the model evaluates the state of combustible materials on the basis of multi-day time series of meteorological data. Using information on the state of combustible materials, wind speed and wind direction, the model estimates front, side and rear speed of fire propagation. The simulation is based on the assumption of an elliptical form of fire spreading. The parameters of the ellipse are uniquely determined by the propagation rates of the fire. In addition, the model introduces a number of speed corrections that are determined by the terrain topography features, hydrogeology, and the possibility of a crown fire ignition.

Simulation of fire development is carried out on a regular grid, the size of which depends on the resolution of satellite data and available computing capabilities. The operational satellite data sets the areas of active burning on the grid. Using the model an ellipse is constructed for each cell in the state of active combustion. The model reproduces the ignition of new grid cells and the spread of fire from them during the development of a fire. The conducted studies showed that the model allows to adequately predict the dynamics of fires in the territory of Russia (Khvostikov et al., 2012, Khvostikov, 2016). Figure 9 shows example of simulation results received by forecast of fire development in 1 day term. The simulation was conducted for detected forest fire in summer period in Nizhniy Novgorod region in 28th of July 2010. At that place, there was catastrophic drought that led to numerous large forest fires in vast region between Moscow and Near-Volga regions. 


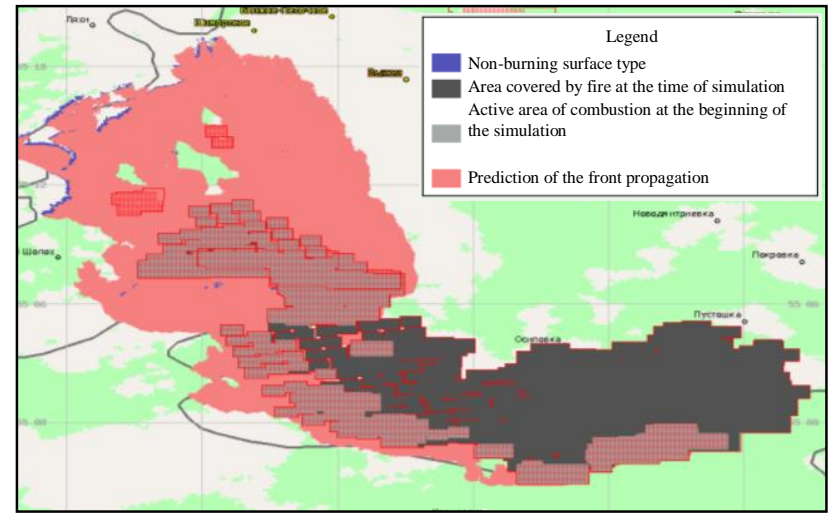

Figure 9. Forecasting the dynamics of fires on the basis of assimilation of the results of processing satellite data into a regionally parameterized model of the development of foci of combustion in Nizhniy Novgorod region in 28.07.2010

(Khvostikov, 2016)

In order to solve the problem of forecasting the dynamics of operating fires, it is necessary to receive actual data on the combustion conditions, which is achieved by integrating the model into the Rosleskhoz information system. The model uses satellite data on the area of active burning, types of combustible materials and terrain topography, as well as current and forecasted meteorological information.

The described model forms the basis for the operational prediction of pyrogenic death of forests. The approach includes the following three stages: 1) obtaining satellite information on the current position of the fire front, 2) forecasting its dynamics for a short period using a simulation model and forecasted meteorological data, 3) obtaining a predictive estimate of the area of dead forests. Estimation of pyrogenic forest death is based on the forecasted area of fire spreading and statistical distributions of the probability of forest death from fires.

In account of simulations, we receive forecasts of the location of damaged forest. It allows us to evaluate finally expected square size of damaged forest and coordinates of its boundary which could be using for retrieval of that site taxonomy. So, eventually we possess all information parameters necessary to evaluate finally expected forest fire damage provided by forecast for requested term according to relations (1-6) (see sec.2.2).

\section{CONCLUSIONS}

The web tools for evaluation consequences of actual disaster event on forest areal are developed. Specialized EO data routines produce a set of products, which are necessary to make prediction of damage extent in given forest terrain for current weather conditions, implement these evaluations.

To this end, special service compares actual state of vegetation canopy, which is retrieved from actual EO information, with historical information, which is extracted from special database that contains information on forest canopy status the most recent to disaster event. To escape actualisation problem, which possibly could be met with in using state forest inventory, work propose to apply information resources of long-term EO data archive of VEGA services that contains multiyear EO data and products describing taxonomy of Russian forest terrains. This information allows not only to estimate the extent of actual damages but also to forecast finally expected disaster extents.
All developed web tools and supported services are implemented in the VEGA family of active satellite data information system integrated with long-term EO data archive.

\section{ACKNOWLEDGEMENTS}

The work is supported by RFBR grant № 16-29-09615 ofi_m. Landsat data were received from the U.S. Geological Survey. Sentinel data were received from Sentinel Online.

\section{REFERENCES}

Balashov, I.V., Bartalev, S.A., Bartalev, S.S., Burcev, M.A., Egorov, V.A., Efremov, V.Ju., Kashnickij, A.V., Loupian, E.A., Mazurov, A.A., Oksjukevich, A.Ju., Proshin, A.A., Sen'ko, K.S., Uvarov, I.A., Kramareva, L.S., 2016. Vozmozhnosti informatsionnoy sistemy kompleksnogo monitoringa lesov "Vega-Primorje" [Possibilities of information system for forest complex remote monitoring Vega-Primorie]. Presentation at XIV All-Russian Open Conference Sovremennye problemy distantsionnogo zondirovaniya Zemli iz kosmosa [Modern problems of Earth remote sensing from space], Moscow. 2016.

Bartalev, S.A., Ershov, D.V., Loupian, E.A., Tolpin, V.A., 2012. Possibilities of satellite service VEGA using for different tasks of land ecosystems monitoring. Sovremennye problemy distantsionnogo zondirovaniya Zemli iz kosmosa, 9(1), pp. 4956.

Bartalev, S.A., Egorov, V.A., Zharko, V.O., Loupian, E.A., Plotnikov, D.E., Khvostikov, S.A., 2015a. Current state and development prospects of satellite mapping methods of Russia's vegetation cover. Sovremennye problemy distantsionnogo zondirovaniya Zemli iz kosmosa, 12(5), pp. 203-221.

Bartalev, S.A., Stycenko, F.V., Egorov, V.A., Loupian, E.A., $2015 \mathrm{~b}$. Satellite assessment of death of the woods of Russia from the fires. Lesovedenie, 2, pp. 83-94.

Bartalev, S.A., Plotnikov, D.E., Loupian, E.A., 2016. Mapping of arable land in Russia using multiyear time series of MODIS data and the LAGMA classification technique. Remote Sensing Letters, 7(3), pp. 269-278.

Bartalev, S.A., Stycenko, F. V., Khvostikov, S.A., Loupian, E.A., 2017. Methodology of post-fire tree mortality monitoring and prediction using remote sensing data. Sovremennye problemy distantsionnogo zondirovaniya Zemli iz kosmosa, 14(6), pp. 176193.

Egorov, V.A., Bartalev, S.A., Loupian, E.A., Uvarov, I.A., 2006. Monitoring of damages of a vegetable cover by the fires according to satellite observations. Izvestiya vysshikh uchebnykh zavedenij. Geodeziya i aerofotosemka, 2, pp. 98-109.

Kashnitskii, A.V., Balashov, I.V., Loupian, E.A., Tolpin, V.A., Uvarov I.A., 2015. Development of the software tools for satellite data remote processing in contemporary information systems. Sovremennye problemy distantsionnogo zondirovaniya Zemli iz kosmosa, 12(1), pp. 156-170.

Khvostikov S.A., Balashov I.V., Bartalev S.A., Efremov V.Yu., Loupian E.A., 2012. Regional scale optimization of wildfire model parameters and modelling of wildfire dynamic using remote sensing data. Sovremennye problemy distantsionnogo zondirovaniya Zemli iz kosmosa, 9(3), pp. 91-100. 
Khvostikov S.A., 2016. Razrabotka imitatsionnyh modeley $i$ kompleksov programm dlia otsenki dinamiki nazemny hekosistem na osnove integratsii dannyh sputnikovogo monitoringa. (Elaboration of imitation models and program complexes for estimations of land ecosystems dynamics on the basis of satellite monitoring data. Cand. tech. sci. PhD thesis), Moscow: IKI RAS, 151p.

Loupian, E.A., Savin, I.Yu., Bartalev, S.A., Tolpin, V.A., Balashev, I.V., Plotnikov D.E., 2011. Sattelite service for vegetation monitoring VEGA. Sovremennye problemy distantsionnogo zondirovaniya Zemli iz kosmosa, 8(1), pp. 190198.

Loupian, E.A., Savorskiy, V.P., Sholin, Yu.I., Aleksanin, A.I., Nazirov, R.R., Nedoluzhko, I.V., Panova, O.Yu., 2012. Up-todate approaches and technology arrangement of Earth observation data applications aimed to solve scientific tasks. Sovremennye problemy distantsionnogo zondirovaniya Zemli iz kosmosa, 9(5), pp. 21-44.

Loupian, E.A., Bartalev, S.A., Tolpin, V.A., Zharko, V.O., Krasheninnikova, Yu.S., Oksyukevich, A.Yu., 2014. VEGA satellite service applications in regional remote monitoring systems. Sovremennye problemy distantsionnogo zondirovaniya Zemli iz kosmosa, 11(3), pp. 215-232.

Loupian E.A., Bartalev S.A., Ershov D.V., Kotel'nikov R.V., Balashov I.V., Burtsev M.A., Egorov V.A., Efremov V.Yu., Zharko V.O., Kovganko K.A., Kolbudaev P.A., Krasheninnikova Yu.S., Proshin A.A., Mazurov A.A., Uvarov A.A., Stytsenko F.B., Sychugov I.G., Flitman E.V., Khvostikov S.A., Shulyak P.P., 2015. Satellite data processing management in Forest Fires Remote Monitoring Information System (ISDM-Rosleskhoz) of the Federal Agency for Forestry. Sovremennye problemy distantsionnogo zondirovaniya Zemli iz kosmosa, 12(5), pp. 222250.

Loupian, E.A., Bartalev, S.A., Balashov, I.V., Bartalev, S.S., Burcev, M.A., Egorov, V.A., Efremov, V.Ju., Zharko, V.O., Kashnickij, A.V., Kolbudaev, P.A., Kramareva, L.S., Mazurov, A.A., Oksjukevich, A.Ju., Plotnikov, D.E., Proshin, A.A., Sen'ko, K.S., Uvarov, I.A., Khvostikov, S.A., Hovratovich, T.S., 2016. Vega-Primorie: complex remote forest monitoring information system. Sovremennye problemy distantsionnogo zondirovaniya Zemli iz kosmosa, 13(5), pp. 11-28.

Russian Federation Government Decree No. 310 of 22.05.2007.

Russian Federation Government Decree No. 1350 of 14.12.2016.

Savorskiy, V., Tishchenko, Y., 2008. Event-Driven Information System Designed for Emergency Applications. In: The International Archives of the Photogrammetry, Remote Sensing and Spatial Information Sciences, Beijing, China, Vol. XXXVII, Part B8, pp. 241-248.

Savorskiy V., Tishchenko Yu., 2009. Upgrade of Space Data Information System to Use in Natural Disaster Emergency. ISRSE 33 proceedings, Stresa, Italy, TS-41-2 (ref.350), 4 pp.

Savorskiy, V., Tishchenko, Yu., 2012. Enhancement of spatial database archive services for disaster response. Applied Geomatics, 4(4), pp. 269-277.

Savorskiy, V., Loupian, E., Balashov, I., Burtsev, M., Proshin, A., Tolpin, V., Ermakov, D., Chernushich, A., Panova, O.,
Kuznetsov, O., Vasilyev, V., 2014. Basic technologies of Web services framework for research, discovery, and processing the disparate massive earth observation data from heterogeneous sources. In: The International Archives of the Photogrammetry, Remote Sensing and Spatial Information Sciences, Suzhou, China, Vol. XL, Part 4, pp. 223-228.

Savorskiy, V., Loupian, E., Balashov, I., Kashnitskii, A., Konstantinova, A., Tolpin, V., Uvarov, I., Kuznetsov, O., Maklakov, S., Panova, O., Savchenko, E., 2016a. VEGAConstellation tools to analize hyperspectral images. In: The International Archives of the Photogrammetry, Remote Sensing and Spatial Information Sciences, Vol. XLI-B4, pp. 235-242.

Savorskiy, V.P., Kotel'nikov, R.V., Bartalev, S.A., Lupian, E.A., Maklakov, S.M., Khovratovich, T.S., 2016b. Razvitie distantsionnykh avomatizirovannykh metodov kontrolia sobliudenia lesnogo zakonodatel'stva pri provedenii rubok [Development of remote authomatic methods of forest legislations control of logging]. Presentation at XIV All-Russian Open Conference Sovremennye problemy distantsionnogo zondirovaniya Zemli iz kosmosa [Modern problems of Earth remote sensing from space], Moscow. 2016.

Savorskiy, V.P., Kotel'nikov, R.V., Bartalev, S.A., Maklakov, S.M., Panova, O.Yu., 2017. Possibilities for obtaining objective quantitative remote assessments of forest damage. Sovremennye problemy distantsionnogo zondirovaniya Zemli iz kosmosa, 14(7), pp. 136-152.

Uvarov, I.A., Matveyev, A.M., Burtsev, M.A., Loupian, E.A., Mazurov, A.A., Proshin, A.A., Savorskiy, V.P., Sudneva, O.A., 2014. Arrangement of distributed work with satellite hyperspectral data for solution of scientific and applied problems. Sovremennye problemy distantsionnogo zondirovaniya Zemli iz kosmosa, 11(1), pp. 322-333.

VEGA, 2018. http://sozvezdie-vega.ru/eng (11 February 2018). 